\title{
The Influence of Ministry of Health Care for Teens Program with Peer Counselors Teens and Proposed Posyandu
}

\author{
Ratna Yunita Setiyani Subardjo ${ }^{*}$ \\ ${ }^{1}$ Psychology Department, Aisyiyah Yogyakarta University, Yogyakarta, Indonesia \\ *Corresponding author. Email: ratnayunita@unisayogya.ac.id
}

\begin{abstract}
Various adolescent behavioral symptoms have featured prominently in the community; some of these behaviors are even criminal. Not only teenagers, but children are also exposed and have become perpetrators of criminal acts. The community itself has been anxious facing these symptoms. So far the biggest concern, which is also the center of attention of many people, is the acts of violence committed young children; this is already a serious situation that needs to be addressed immediately. Another more worrying thing is the age of the perpetrators of criminal acts are increasingly younger. Consequently, efforts need to be undertaken to overcome this. The purpose of this study was to determine the influence of peer counselors and a pilot program implementation for Posyandu teenagers in the District of the Kraton, including the planning and implementation of health promotion programs by the Kraton psychologists in the primary healthcare setting aimed at assisting offenders and victims in cases involving children and teenagers in the field. This study used a qualitative approach with case analysis method and compared the changes for patients that occurred after the program compared to the baseline, as well as chronicling the researcher's field experience. Planning efforts for PKPR with the peer counselor program is still in progress and advocacy efforts have been completed. Suggestions from this research program include: maximizing maintaining peer counselors, and pilot programs in the area of juvenile Posyandu shared across sectors and effective programs of peer counselors and the presence of posyandu adolescents are indeed instrumental in improving the mental health of children and adolescents. Such programs are still scarce in Indonesia, which prompts the researchers to propose a number of possible interventions to be considered as one way to save the future generations. Keywords: health care teens, peer counselors, adolescent Posyandu
\end{abstract}

\section{INTRODUCTION}

Kraton as one of areas in Yogyakarta, is included as a densely populated area. The existence of primary health center in Kraton area is very helpful for community to obtain health services at a primary level. People in Kraton area are easily exposed to hedonism. Many unexpected behaviors occur especially in adolescents. Based on the data from cases on psychology in February 2014 - May 2018, there were 60 cases of Unwanted Pregnancy, 50 cases of child sexual abuse, 35 cases of free sex, 12 cases of drug use, 105 cases of smoking in adolescents, 50 cases of quitting smoking, 245 psychosomatic cases of which $65 \%$ were experienced by adolescents; especially when approaching exams, and 28 psychotic cases.

The number of working parents and the little time parents have for their children drives adolescents to go to their friends when they face any problems. Adolescents prefer their peers as trusted role models to their parents, teachers or other families. They follow things done by their peers which are considered good and right. Aside from trusting their peers as a as role models, adolescents also feel more secure and feel happy when they can get the information they need from their peers, compared to their parents. For example, adolescents who want to know the ins and outs of "wet dreams", they will not ask their parents, or teachers, they prefer asking their peers, even though their peers may not necessarily have good and correct information. This kind of phenomena encourages researchers as part of health workers at Kraton Health Center to be able to reach out to adolescents in Kraton area and invite parts of adolescents as cadres/ambassadors who can play a role in inviting their friends to be aware of their physical and psychological health. Therefore, we tried to run a peer counselor program and form the so-called Posyandu Remaja (Adolescent Primary Health Center) so that the number of adolescent problems occurring in Kraton sub-district environment can be decreased. Hence, young people who are expected to be successors to the aspirations of the nation can come forward and act positively. By doing so, this nation will become a strong nation with healthy human resources both physically and psychologically.

The study is to find out the influence of peer counselor program and pioneer of Posyandu Remaja (Adolescent Primary Health Center) implementation at Kraton Subdistrict in Yogyakarta. Based on the theoretical benefit, the study enriches theoretical insights in field of psychology and based on practical benefit, the study can be used as an effort for regional health psychologists/health promotion 
personnel to provide intervention, rehabilitation, advocacy and promotion for adolescents, so that they can approach adolescents and invite them to do many positive things as a periodic activity. In addition, practical purpose of the study is to propose programs in the study at the respective working areas such as primary health centers/other environments in educating adolescents.

The word "adolescence" comes from the Latin word adolescence which means to grow or to grow maturity [1]. Many figures provide definitions of adolescence, such as DeBrun who defines adolescence as a period of growth between childhood and adulthood [2]. Do not provide explicit definition about adolescent but they implicitly define adolescent through a definition of adolescence [1].

Adolescence is a period of developmental transition between childhood and adulthood which generally starts at the age of 12 or 13 years and ends at the age of the late teens or early twenties [3]. According to Adams \& Gullota [4], adolescence includes ages between 11 and 20 years. Whereas Hurlock (1990) divides adolescence into early adolescence (13 to 16 or 17 years) and late adolescence (16 or 17 years to 20 years). The early and late adolescence are distinguished by Hurlock because in the late adolescence the individual has achieved a developmental transition closer to adulthood [1].

Adolescence is a period between childhood and adulthood. On the contrary, Anna Freud (in Hurlock, 1990) argues that during adolescence there is a development process including changes related to psychosexual development, and also changes in relationships with parents and their aspirations. The formation of aspirations is the process of forming a future orientation [3].

The developmental transition in adolescence means that part of the development of childhood is still experienced but that part of adulthood has already been reached [5]. Part of childhood includes biological growth processes such as height that keeps growing. Meanwhile, part of adulthood includes the maturity process of all organs including the reproductive function and cognitive maturity which is characterized by being able to think abstractly [3]

The developmental aspects in adolescents can be divided into two: Physical development, i.e., changes in the body, brain, sensory capacity and motor skills [1]. Changes in the body are characterized by height and weight gain, growth of bones and muscles, and maturity of sexual organs and reproductive functions. The adolescents' body begins to switch from the body of a child whose character is growth into an adult body whose character is maturity. Physical changes in the brain so that its structure is more perfect and it increases cognitive abilities [2]. Cognitive Development; according to Piaget an adolescent is motivated to understand the world because of their biologically adapted behavior. In Piaget's view, adolescents actively build their cognitive world. The obtained information is not immediately understood in their cognitive schemes. Adolescents have been able to distinguish between things or ideas that are more important than other ideas, then they also connect these ideas [6].

Along with the changing of era, diverse behavior or deviant behavior of adolescents often cause anxiety and problems for others. The deviation is certainly related to morals that appear as a delinquency or crime. Moral comes from the
Latin Mores which means procedures, habits, behavior, and customs in life [7]. Morals as wrong or right guidelines for someone's behavior determined by society. Morals as patterns of behavior, principles, concepts and rules used by individuals or groups related to good and bad. Moral is a person's habit to behave better or worse in thinking about social problems, especially in moral actions [2].

Moral is essential for a society, nation and people. If the morale is damaged, the peace and honor of the nation will be lost. Therefore, to remain survive as a respectable nation, it is necessary to pay attention to moral education, both in the family, school and society [8]. Healthy, of course, is not only physically, but also psychologically. Some cases existing in Kraton health center environment related to adolescents, are related to health. Some cases that often appear and are increasingly found are cases of adolescent smoking, use of drugs for specific purposes, use of psychotropic drugs, sexual violence, stress (physical symptoms that can affect chronic conditions or extreme stress). Psychological symptoms such as anxiety, sadness, eating disorders, depression, insomnia and sexual activity also appear [9].

Adolescents report several reasons for sexual activity which comes from the encouragement of the group; to love and be loved, to try and have fun. However, some teenagers cannot make value decisions, the skills needed to clarify something important at a young age and also to add basic knowledge about contraception and STDs [3].

The advancement of technology and the development of the times made it easy for adolescents to access several things related to technology. The various types of gadgets and the internet that is very open make them pampered and often forget themselves. The role of parents, health personnel, friends and teachers is very significant to keep adolescents from being too naughty. But in reality, for the adolescents, friends are everything and their friends become a place to go and to complain about their problems. In fact, there are not a few friends who often invite adolescents to do negative things, such as trying cigarettes, drugs, join gangs, and so on.

\section{RESEARCH METHODS}

The type of the study was qualitative. The study was conducted at Kraton Health Center in Yogyakarta City based on the work experience of the researcher as a psychologist at Kraton Health Center, data from the health promotion division, the Head of Kraton Health Center, survivor, community cadre, and Kasubbag TU (head of administration sub division) of Kraton Health Center, during the period from February 12014 to the present. The method of data collection was through observation [10], interviews, incoming case findings, and physical documentation in a form of status data and psychological reports and photos.

\section{RESULTS AND DISCUSSION}

The results of the health promotion program carried out by psychologists in the field are; the presence of a correct understanding of reproductive health that makes adolescents able to maintain their behavior from a free and irresponsible lifestyle. Based on the conditions in the field and cross- 
profession communication at the Puskesmas, now $100 \%$ of patients/clients are willing, if it is necessary, to be referred to a psychologist with complex cases of adolescents, which sometimes referral comes from peer counselors and Posyandu Remaja programs.

Health improvement as motivation to become a state of prosperity and actual health potential. Prevention is to avoid pain, detect as early as possible, and maintain optimal function when ill conditions come. Nurses have a great opportunity and responsibility to help women for not understanding risk factors and to motivate them to accept a healthy lifestyle in preventing disease. Nutrition, exercise, stress management, smoking cessation, alcohol consumption restrictions, self-screening period, implementation, additional hormone therapy, sexual issues [1].

Peer counselors and youth Posyandu programs are an advocacy effort for young people. The objectives of the youth peer counselors and Posyandu programs provided by psychologists to adolescents in Kraton sub-district environment are; is there any influence between the peer counselor program and adolescent Posyandu in Kraton subdistrict environment on adolescent reproductive health, knowledge of the importance of reproductive health education and drug use for adolescents, adolescent selfawareness as a model for other adolescents and how adolescents' understanding of the importance of healthy lifestyles.

\section{CONCLUSION}

Adolescent Health Care Services with peer counselors and Posyandu Remaja programs have a positive influence on adolescents in Kraton sub-district environment. The positive influence can be seen from the increase in knowledge about reproductive health that makes adolescents able to maintain their behavior from a free and irresponsible lifestyle. In addition, it can also be seen from the decrease in cases of Unwanted Pregnancy, smoking at an early age and free sex in Kraton Yogyakarta sub-district area.

\section{ACKNOWLEDGMENT}

The author gratefully acknowledgment sincere support from Ministry of Health Care and Aisyiyah Yogyakarta University for the completion of this study.

\section{REFERENCES}

[1] R. Beyth-Marom, L. Austin, B. Fischhoff, C. Palmgren, and M. Jacobs-Quadrel, "Perceived Consequences of Risky Behaviors: Adults and Adolescents,” Dev. Psychol., vol. 29, no. 3, pp. 549563, 1993.

[2] A. Anggraeny, K. Wahyu Yuniarti, and U. Kim, "Happiness orientations among adolescents raised in urban and rural areas," Indigenous, vol. 13, no. 1, pp. $15-28,2015$.

[3] D. Yuniar Angelina, "Pola Asuh Otoriter, Kontrol Diri Dan Perilaku Seks Bebas Remaja SMK," Pers. Psikol. Indones., vol. 2, no. 2, pp. 173-182, 2013.

[4] J. Psikologi and I. Vol, "Penyesuaian Diri Remaja Putri Yang Menikah Muda," Psikis J. Psikol. Islam., vol. 1, no. 1, pp. 11-21, 2016.

[5] J. Setyawan, R. Marita, I. Kharin, and M. Jannah, "Dampak Psikologis Pada Perkawinan Remaja Di Jawa Timur," J. Penelit. Psikol., vol. 7, no. 2, pp. 15-39, 2016.

[6] J. Fadilah, "Consumer Insight Remaja Pada Seating Area Convenience Store 7-Eleven," J. Komun. Akad. Komun. BSI Jakarta, vol. Vol 7, no. September, pp. 111, 2016.

[7] R. Y. Setiyani, "Layanan psikolog di Puskesmas Yogyakarta, solusi deteksi gangguan jiwa di level bawah," Conversat., 2018.

[8] R. Y. S. S, I. Laksmi, and S. Urbayatun, "Pelatihan Pengasuhan untuk Meningkatkan Pemahaman dan Kualitas Pengasuhan Orang Tua Anak GPP/H," Humanit. (Fakultas Psikol. Univ. Ahmad Dahlan), vol. 11, no. 1, pp. 55-68, 2014.

[9] R. S. U. Yusuf, "Depresi," Psikohumanika, vol. 3, no. Psikologi Klinis, pp. 1-6, 2018.

[10] H. Hasanah, "TEKNIK-TEKNIK OBSERVASI (Sebuah Alternatif Metode Pengumpulan Data Kualitatif Ilmu-ilmu Sosial)," At-Taqaddum, vol. 8, no. 1, p. 21, 2017 